\section{Strategjsko upravljanje portfolijom inovacija}

\author{
Ljiljana Stanković, Suzana Đukić
}

\section{UVOD}

Konkurentska prednost je rezultat dejstva različitih faktora. Poslovni uspeh savremenog preduzeća uslovljen je njegovom sposobnošću da kontinuirano usklađuje svoje resurse i sposobnosti sa potrebama okruženja. U uslovima stalnih promena potreba tržišta, sposobnost generisanja i tržišna kreativnost i sposobnost generisanja ideja o novom proizvodu/usluzi i njihovom marketing programu su ključni faktori uspeha preduzeća. Usklađivanje mogućnosti preduzeća sa okruženjem je uspešnije ukoliko je rezultat kontinuiranih inovacija proizvoda/usluga i procesa.Sposobnost kontinuiranog prilagođavanja proizvoda i usluga i uvođenja novih je kritični faktor poslovnog uspeha. To često znači modifikaciju postojećih, eliminisanje neuspešnih i/ili uvođenje novih proizvoda i usluga. Trajna konkurentska prednost se može obezbediti inovativnijim i boljim proizvodom u odnosu na konkurentske.

Upravljanje poslovnim portfolijom u najširem smislu reči dobija sve više na značaju kako u teoriji tako i u praksi strategijskog menadžmenta. Koncept se koristi kako bi se, kroz odgovarajuće faze u procesu upravljanja, obezbedilo efektivno i efikasno reagovanje preduzeća na promene u okruženju. Strategijsko upravljanje portfolijom inovacija je limitirajući faktor uspeha preduzeća. Osnovni cilj je da se izabere optimalna kombinacija kao i redosled ponuđenih projekata inovacija kako bi se ostvarili strategijski ciljevi organizacije. Upravljanje portfolijom inovacija je dinamičan proces donošenja odluka koji omogućava usklađenost sa poslovnom strategijom (Cooper \& Edgett, 2014). Neki autori (npr. Levine, 2005) ovaj process objašnjavaju kao set poslovnih praksi koji projekte inovacija čvrsto povezuje sa ostalim poslovnim aktivnostima. Prema nekim shvatanjima (PMI, 2006) upravljanje portfolijom projekata (a projekti su rezultat invacija) odnosi se, pre svega, na selekciju i podršku projektima ili ulaganja u programe. Koliko je značajno ovo pitanje pokazuje i opredeljenje da se definišu Standardi za upravljanje portfolijom projekata (PMI, 2006, str. 5). Standardima je definisano da „portfolio menadžment kombinuje: (a) organizacioni fokus da se obezbedi da se projekti odabrani za ulaganje usklade sa portfolio strategijom i (b) fokusiranost upravljanja projektima koje se zasniva na efektivnoj realizaciji projekata u skladu sa definisanim resursima“. Može se zaključiti da se posebno naglašava potreba strategijskog pristupa, ne samo u izboru određenih projekta ino-
Sažetak: U ekonomiji zasnovanoj na znanju strategijsko upravljanje portfolijom inovacija postaje sve više kritični faktor uspeha preduzeća. Kreiranje vrednosti za sve učesnike u lancu je uspešnije ukoliko se zasniva na efikasnoj alokaciji resursa i unapređenju performansi vezanih za inovacije. Brojna istraživanja pokazuju da su bolje pozicionirane kompanije koje svoju konkurentnost zasnivaju na efikasnom razvijanju i eksploataciji inovacija. U procesu odlučivanja menadžment preduzeća je pred stalnim izazovom kako što efikasnije alocirati resurse i sposobnosti, kako u kratkom tako i u dugom roku. U radu su prikazani preliminarni rezultati realizovanog empirijskog istraživanja koje se odnosi na strategijsko upravljanje portfolijom inovacija u deset izabranih preduzeća u Srbiji. Strukturu rada čine sledeći delovi: teorijski okvir, objašnjenje svrhe i metodologije istraživanja, diskusija rezultata i zaključna razmatranja, uključujući ograničenja i smernice za buduća istraživanja.

KIjučne reči: Strategijsko upravljanje, portfolio inovacija, vrednovanje inovacija, inovacione performanse 
vacija, već i u nameeri da se obezbedi njihova uspešna tržišna komercijalizacija.

Termin inovacija ima različito značenje, kako u teoriji tako i u praksi. Analizom relevatnih teorijskih izvora i praktičnih istraživanja pokazuje da postoje određene razlike. Može se zaključiti da u teorijskim istraživanjima sve više pažnje privlači holistički pristup koji uključuje proizvode, usluge i različite poslovne procese. U savremenoj privredi sve je manje čistih proizvoda i usluga. Vrednost za potrošača nije samo fizički proizvod ili čista usluga već, sve više, predstavlja svežanj koristi koji se nudi potrošaču, a koji se kreira realizacijom brojnih aktivnosti u okviru različitih poslovnih procesa.

S druge strane, u upotrebi su različite metodologije kojima se definiše inovacija i koje se koriste u praktičnim istraživanjima sa ciljem da se analizira i oceni inovativnost na različitim nivoima (država, kompanija). Prema metodologiji koju koristi Republički zavod za statistiku Srbije (Statistički godišnjak Republike Srbije, 2011, str. 342) inovacija je objašnjena na sledeći način „inovacija je primena novog ili značajno poboljšanog proizvoda, usluge ili procesa, marketinške metode ili nove organizacione metode u poslovanju, organizaciji rada ili odnosima poslovnog subjekta sa okruženjem"(OECD, 2005).

U OECD-ovom priručniku je inovacija proizvoda usluge definisana kao „lansiranje na tržište...“

U Priručniku OECD-a inovacija proizvoda/usluge definisana je kao „lansiranje na tržište dobara ili usluga sa novim ili znatno poboljšanim karakteristikama ili mogućnostima korišćenja. Ovo uključuje značajna poboljšanja tehničkih karakteristika, komponenti i materijala, ugrađenog softvera,oijentacija na korisnikai ili drugih funkcionalnih karakteristika" (OECD, 2005). U skladu sa navedenim shvatanjem bitno je da inovacija bude nova za preduzeće (organizaciju i instituciju), iako je poznata tržištu.

Inovacij procesa, po navedenom izvoru, predstavlja... „implementaciju novog ili značajno poboljšanog načina proizvodnje i isporuke. Ovo uključuje značajne promene u tehnici, opremi ili softveru" (OECD, 2005). Prema istom izvoru inovacije proizvoda/usluge i inovacije procesa nazivaju se tehnološkim inovacijama.

Pored navedenih, veoma su značajne i inovacije u organizaciji poslovnog subjekta koje se objašnjavaju kao "primena novih ili znatnih promena u strukturi ili metodama menadžmenta, s namerom da se poboljša korišćenje znanja, kvaliteta proizvoda/usluge ili da se poveća efikasnost poslovnih tokova" (OECD, 2005).

Najzad, inovacja u marketingu predstavlja... ,primenu nove marketinške metode što uključuje značaj- ne promene u dizajnu proizvoda, pakovanja, plasmanu i promociji kao i naplaćivanju proizvoda" (OECD, 2005).

Polazeći od shvatanja inovacija u relevatnoj literature, kao i od navedenih definicija korišćenih u praktičnim istraživanjima, možemo zaključiti da portfolio inovacija čine:

- Inovacije proizvoda - koje obuhvataju inovacije svih obeležja fizičkog proizvoda uključujuči dizajn i pakovanje (koje su u prethodnim definicijama označene kao inovacije u marketingu)

- Inovacije usluga - inovacije usluga kao paketa koristi i

- Inovacija procesa - pored proizvodnje i isporuke vrednosti uključeni su i ostali poslovni procesi koji sadrže različite aktivnosti u lancu vrednosti.

\section{UPRAVLJANJE PORTFOLIJOM INOVACIJA - PREGLED LITERATURE}

Usklađivanje strategijskih prioriteta je sve češće predmet istraživanja u literaturi iz oblasti strategijskog menadžmenta. Jedna od centralnih tema je usklađivanje portfolija inovacija sa poslovnom strategijom organizacije. Tradicionalni pristup upravljanju inovacijama, poznat kao strukturalna inovaciona paradigma (Simenis \& Hart, 2009, str. 77-87), zasnovan je na orijentaciji na potrebe potrošača i težnji za rešavanje njihovih problema brže i bolje od konkurencije realizacijom strukturnih promena u preduzeću. Krajnji cilj ovih promena, koje dovode do prilagođavanja poslovnog modela, je kreiranje ponude vrednosti uz što niže troškove, odnosno uz cenu kao osnovu za sticanje konkurentske prednosti. Međutim, brojne promene koje karakterišu savremeno poslovanje nameću potrebu promene pristupa inovacijama. U fokusu novog pristupa je kreiranje vrednosti za sve učesnike u lancu vrednosti što se postiže razvijanjem odnosa razvnovrsnih poslovnih mreža.

Istraživanja pokazuju da je, i pored povećanog interesovanja za ovu temu, literatura o usklađivanju poslovne strategije i strategije upravljanja inovacijama, i dalje oskudna. Analizom publikovanih istraživanja može se zaključiti da još uvek dominira funkcionalni pristup strategijama i da je relativno malo primera koji pokazuju da je ostvaren strategijski sklad i da postoji čvrsta veza i usaglašenost poslovne strategije i izbora inovacija čija realizacija bi doprinela uspešnom strategijskom pozicioniranju (Bard i sar., 1988; Cooper \& Edgett, 2014; Englund \& Graham, 1999). 
Analiza upućuje na zaključak da se još uvek značajna pažnja usmerava na formulisanje srategije, ali ne i na njenu implementaciju.

Ipak, ispostavilo se da je problem usklađivanja mnogo kompleksniji nego što bi se to na prvi pogled moglo zaključiti. Zbog toga, poslednjih desetak godina ovaj problem privlači pažnju istraživača (npr. Artto \& Dietrich, 2004; Jamieson \& Morris, 2004; Anderson \& Merna, 2003; Srivannboon \& Milošević, 2006). ${ }^{1}$

Potrebu za strategijskim pristupom u upravljanju portfolijom inovacijama uzrokuju brojni faktori. Preduzeća danas posluju u ekonomiji koja je zasnovana na znanju i koja se bitno razlikuje u odnosu na tradicionalnu ekonomiju. Razlike se, pre svega ogledaju u sledećem: ${ }^{2}$

\section{- Imperativ racionalnog trošenja resursa-U}

ekonomiji zasnovanoj na inovacijhama racionalna upotreba resursa i smanjivanje troškova postaje imperativ. On se postiže različitim strategijama: u industrijskoj ekonomiji dominantan vid ušteda je vertikalna integracija, $\mathrm{u}$ ekonomiji zasnovanoj na inovacijama poželjna je fleksibilnost i razvijanje otvorenih poslovnih modela;

- Ponuda personalizovanih rešenja u skladu za zahtevima kupaca - Za razliku od ponude standardizovanih proizvoda i usluga koja je dominantna $\mathrm{u}$ industrijskoj ekonomiji, u ekonomiji zasnovanoj na in ovacijama preduzeća kreiraju ponudu vrednosti u skladu sa zahtevima i vrednostima pojedinih kupaca, odnosno segmenata tržišta, čije zdovoljavanje doprinosi ostvarivanju ciljeva ključnih stejkholdera preduzeća;

- Slabljenje granica između kompanija i zajedničko kreiranje vrednosti - U novoj ekonomiji zasnovanoj na znanju, sve više se "gube“ granice između industrija i kompanija, jačaju veze i odnosi i dolazi do umrežavanja u procesu kreiranja i isporuke vrednosti;

- Jačanje konkurencije - Tržišna infrastruktura u industrijskoj ekonomiji ograničavajuće je delovala na brze promene. U ekonomiji zasnovanoj na in ovacijama konkurencija je sve izraženija, a tržišna infrastruktura podstiče promene;

- Promene u strukturi moći - U ekonomiji zasnovanoj na in ovacijama postoji znatno više izvora

\footnotetext{
Na primer, veliki broj autora izražava shvatanje da strategijski prioriteti na funkcionalnom nivou treba da budu usklađeni sa strategijama na nivou poslovne jedinice i funkcije (Jackson i sar., 2003, Srivannboon \& Milošević, 2006; Blichfeldt \& Eskerod, 2008).

2 Prilagođeno prema Davenport, Leibold \& Voelpel, 2006, str. 21.
}

za kreiranje vrednosti i dolazi do pregrupisavanja pojedinih stejkholdera što bitno utiče na njihovu poziciju. S obzirom na to da je konkurencija sve izraženija, pregovaračka moć potrošača i dobavljača raste, što zahteva odgovarajuće strategijsko reagovanje kroz različite forme umrežavanja;

- Promena poslovnih modela - U ekonomiji zasnovanoj na inovacijama izraženija je potreba za razvijanjem novih poslovnih modela koji stimulišu efikasno kreiranje i isporuku superiorne vrednosti za sve uključene subjekte u lancu vrednosti;

- Povećanje značaja nematerijalne imovine i potreba razvijanja novih sistema merila za vrednovanje iste.

Strategijsko upravljanje portfolijom inovacija doprinosi ostvarivanju sinergetskih efekata (Rajegopal i sar. 2007): bolja koordinacija između različitih departmana u organizaciji, čvršće usklađivanje sa organizacionim ciljevima, optimalna vrednost portfolija, povećana transparentnost, efikasnije odlučivanje, racionalnije korišćenje svih resursa i sposobnosti preduzeća. Upravljanje pojedinačnim projektima inovacija, koje nije zasnovano na holističkom pristupu, veoma često je rizična poslovna odluka.

Rani teorijski modeli inovacionih aktivnosti imali su uglavnom linearan pogled na prirodu inovativnog procesa. Inovacija je viđena kao niz faza ili aktivnosti koje je trebalo izvesti na sekvencijalni način. Linearni proces je započinjao aktivnostima istraživanja, sledili su razvoj i dizajniranje, a zatim i pilot proizvodnja. Posle ovoga, sledile su masovna proizvodnja i komercijalizacija. Međutim, na osnovu istraživanja upravljanja inovacijama tokom 70-tih i 80-tih godina, zaključeno je da je proces u suštini nelinearan i iterativan, da postoji veliki broj povratnih sprega između različitih aktivnosti. Problemi otkriveni tokom faze dizajniranja, npr. mogu dovesti do novog istraživanja. Promene odluka vezanih za inženjering, još jedna su ilustracija nelinearnosti procesa. One signaliziraju promene dizajna, čak i ako je proizvod već lansiran na tržište.

Iako se u savremenim uslovima poslovanja sve više zagovoraju otvoreni model i promena pristupa upravljanja inovacijama, i dalje se u poslovnoj praksi koriste modeli bazirani na fazama, tokom kojih inovacija postepeno postaje rafinisanija i određenija. $U$ procesu razvoja novih proizvoda $\mathrm{i} / \mathrm{ili}$ usluga koriste se analize na osnovu kojih se odlučuje da li proces nastaviti. Fazama procesa razvoja inovacija još uvek se upravlja na sekvencijalni način. U bitno izmenjenom poslovnom okruženju, upravljanje aktivnostima, funkcijama i procesima, koji su isprepleteni i međusobno uslovlje- 
ni, zahteva i odgovarajući pristup upravljanju portfolijom inovacija. Proces inovacija je postao dinamičniji i adaptivniji. Upravljanje inovacionim lancem sve više se zamenjuje pristupom inovaciona spirala koji ukazuje na kontinuirani niz iteracija kojima se kreiraju prilagođena rešenja za izabrane segmente potrošača.

Kreiranje prilagođene vrednosti zahteva sveobuhvatniji, holistički, pristup koji postavlja nove zahteve menadžerima. Menadžerima su potrebna nova znanja i veštine kako bi razumeli kako se kreira vrednost ne samo za potrošače i vlasnike, već i za ostale ključne stejkholdere. Potrebne su sposobnosti da se, odgovarajućom strategijskom analizom, ostvari integracija aktivnosti u okviru lanca vrednosti koja će dovesti do kreiranja odgovarajuće ponude vrednosti.

Upravljanje portfolijom inovacija je efikasnije ukoliko se na adekvatan način grupišu i ocene potencijalne vrednosti različitih tipova inovacija. U referentnoj literaturi, u zavisnosti od izabranih kriterijuma i pristupa koji se koriste, navode se različiti tipovi inovacija. Tipologija inovacija je važna jer svaki tip inovacija zahteva određena ulaganja, vreme razvijanja, strategije osvajanja tržišta u procesu lansiranja i strategije u različitim fazama životnog ciklusa proizvoda. Jedna od često analiziranih novijih kategorizacija je ona koju su razvili Kim Clark i Steve Wheelwright sa Harvard Business School (2011). Oni prave razliku između: izvedenih projekta, projekata platformi i projekata preokreta. Analizom kategorizacije projekata inovacija koju su razvili Nagsi i Tuff (Nagsi \& Tuff, 2012, str. 69) zaključujemo da nema suštinskih razlika u njihovom pristupu u odnosu na prethodno citirane autore. Naime, polazeći od kriterijuma kako pobediti i gde ostvariti vrednost oni su identifikovali tri tipa inovacija koji zahtevaju različite strategijske pristupe: inovacije na postojećim proizvodima za postojeće kupce, srodne i transformacione inovacije. Slična tipologija koja polazi od kriterijuma da li inovacija menja tržište je na neprekidne i uznemirujuće (Christensen \& Raynor, 2003, str. 32-33.). Neprekidne inovacije se dalje posmatraju kao:

- Inkrementalne - predstavljaju poboljšan postojeći proizvod (osnovni concept proizvodnje je nepromenjen) koji se nudi na postojećem tržištuu;

- Modularne - Osnovna arhitektura proizvoda je ista, ali je promenjen osnovni koncept proizvodnje, nameće potrebu traženja novog znanja za proizvodnju što nije slučaj kod inkrementalnih inovacija;

- Arhitektonske- Ove inovacije zahtevaju rekonfiguraciju postojećeg načina povezivanja različitih komponenti i funkcionisanja sistema. Rezultat primene ovih inovacija je promena osnovnog koncepta proizvoda što je pouzdana osnova za sticanje održive konkurentske prednosti i

- Revolucionarane inovacije - Nastaju kao rezultat uspostavljanja novog načina proizvodnje komponenti i njihovo povezivanje u odgovarajuću arhitekturu. Vođene su tehnologijom koja kreira novo tržište (Mohr \& Slater, 2006, str.19; Henderson \& Clark, 1990, str. 21-23)

Inovativne aktivnosti imaju različite ciljeve. Jedan od osnovnih je smanjivanje rizika, što se može ostvariti korišćenjem postojećih proizvoda i aktive opsluživanjem postojećih tržišta. To se postiže realizacijom suštinskih inovacija, odnosno izvedenih projekata, kroz inkrementalna poboljšanja postojećih proizvoda i usluga.

Za uspešan rast i razvoj preduzeća, pored kratkoročnih, veoma je važno realizovati i dugoročne strategijske ciljeve. To se može postići uspešnim proširenjem postojećih na nove poslove (nove za preduzeće) ulaskom na srodna tržišta, realizacijom proizvoda platforme odnosno srodnih inovacija. Moguće je kreirati nove generacije proizvoda/usluga za postojeća tržišta. Ovi projekti inovacija popunjavaju prostor između izvedenih i projekata preokreta. Proizilaze iz projekata preokreta, i predstavljaju značajno produženje i razvoj novih strategija.

Transformacione, odnosno inovacije preokreta, menjaju ili ruše pravila konkurentske igre. One imaju potencijal da iz osnova preokrenu ne samo tehnološke, već i ostale kapacitete preduzeća, ali i da kreiraju nova tržišta (Mobornj \& Kim, 2007). Najveći izazov za strategijski menadžment i marketing je kako efikasno upravljati inovacijama kao integracionim sistemom sa ciljnim portfolijom, da bi one bile pouzdan pokretač rasta (Milisavljević, 2012, str. 342). Zadatak menadžmenta je kreiranje uravnoteženog portfolija inovacija koji će doprinositi unapređenju poslovnih performansi preduzeća. To zahteva uskladjivanje strategijskih ciljeva upravljanja portfolijom inovacija.

\section{KREIRANJE URAVNOTEŽENOG POTRFOLIJA INOVACIJA}

Strategijsko upravljanje projektima inovacija pretpostavlja uključivanje različitih aktera u preduzeću (na različitim nivoima odlučivanja, različitim poslovima i funkcijama) sa često suprotstavljenim interesima. Konfliktnost interesa i uloga u procesu odlučivanja 
mogu doprineti neracionalnom korišćenju resursa i sposobnosti preduzeća, što se odražava i na njegovo pozicioniranje na tržištu. Prisutno je kontinuirano nadmetanje za ograničene resurse, ali i podršku top menadžmenta za određene projekte inovacija. Problem se dodatno komplikuje kada su, kroz različite uloge u izboru i realizaciji projekata inovacija, uključeni i subjekti iz eksternog okruženja sa svojim ciljevima i interesima. Da bi se potencijalni konflikti uspešno prevazilazili potrebno je: istraživati prirodu procesa na osnovu kojih se oblikuje strategijsko odlučivanje, pregovaranjem rešavati konflikte, istraživati prirodu interpretativnih prepreka kako bi se bolje razumele snage koje verovanja prevode u odgovarajuće strategijske odluke.

Savremena preduzeća koriste različite načine za upravljanje kolekcijom svojih inovacionih aktivnosti. Opšti zaključak koji se može izvesti na osnovu analize brojnih istraživanja je da je strategijski uspeh izvesniji ukoliko se koriste strategije uravnoteženog portfolija, uzimajući u obzir kratkoročne i dugoročne imperative poslovne strategije. Zbog toga je potrebno razvijati različite projekte koji se predlažu u portfoliju inovacija, kroz dimenzije koje doprinose tome da njihov doprinos ukupnim poslovnim performansama preduzeća bude još eksplicitniji. Često korišćeni kriterijumi za ocenu vrednosti inovacija su:

- Distribucija očekivanih prinosa i rizika - Analiza očekivanih prinosa je polazna osnova za vrednovanje inovacija u portfoliju ${ }^{3}$. Uporedo sa procenom potencijalnih prinosa neophodno je oceniti potencijalne rizike. Logično je da rizičniji projekti obećavaju i veće prinose. Ovo je tipično za transformacione projekte. Suštinski (izvedeni) projekti su tipičan primer projekata koji uključuju mali rizik, ali istovremeno omogućavaju ograničene prinose.

- Vreme za tržišnu realizaciju - Uravnoteženi portfolio podrzumeva uskađivanje vremenskih dimenzija realizacije projekata inovacija: kratkoročne i dugoročne. Nije poželjno projekte orijentisati previše ni na kratak ni na dugi rok, jer to može ugroziti strategijske ciljeve razvoja preduzeća. Potrebno je u okviru portfolija pažliivo izvršiti

\footnotetext{
${ }^{3}$ U proceni vrednosti inovacija polazi se od ciljeva preduzeća i izabranih strategija rasta i razvoja, kompetentnosti preduzeća u ključnim funkcionalnim područjima i procesima, usaglašenosti sa postojećim izvorima i sposobnostima preduzeća i sl. (Milisavljević, 2006, str. 225; Doyle \& Stern, 2006, str.214-215; Senić, 2007, str. 276-277.)
}

izbor projekata inovacija u skladu sa potrebama efikasnog upravljanja tržištem.

- Životni ciklus proizvoda/usluge i tehnologije - Proizvodi/usluge i tehnologije imaju različite krive životnog ciklusa. Često je to kriva S oblika. Posle polazne (embrionske) faze, često se brzo razvijaju, a prodaja brzo raste (životni ciklus proizvoda) ili se poboljšava tehnološka performansa (životni ciklus tehnologije). Međutim, postoje ograničenja rasta i za proizvode i za tehnologiju što dovodi do faze zrelosti, kada prodaja stagnira, a prinosi opadaju. Zrele tehnologije i proizvodi se ili zamenjuju novima, ili se podmlađuju srodnim i transformacionim inovacijama. Teško je uspešno upravljati portfolijom u kome dominiraju suštinske inovacije, sa malim učešćem srodnih inovacija. Bez transformacionih inovacija kojima se kreiraju nova tržišta veoma je teško ostvariti uspešan razvoj preduzeća u dugom roku.

- Nivo familijarnosti sa tržištem i tehnologijom. Što je manje organizacija upoznata sa tehnološkim mogućnostima koje će se uključiti u projekte inovacija i sa tržištima gde se očekuje komercijalizacija, postoji veći rizik i veća potreba za saradnjom sa stejkholderima iz eksternog okruženja. Familijarnost sa tržištem i tehnologijom pruža još jedan uvid u prirodu portfolija inovacija preduzeća.

Uspešno upravljanje portfolijom inovacija pretpostavlja usaglašenost aktivnosti na strategijskom i operativnom nivou. Kritični je uticaj toka informacija i obrazaca komunikacije na realizaciju inovacionih aktivnosti što uzrokuje to da se značajna pažnja posvećuje ovom problemu. Nije dovoljno uspešno razvijati samo intra-organizacione i među-funkcionalne obrasce komuniciranja potrebnih tokom procesa upravljanja portfolijom inovacija. U savremenim uslovima poslovanja, kada je neophodno razvijati nove poslovne modele, i u okviru njih otvoreni model inovacija, preduzeća moraju više sarađivati sa eksternim okruženjem. Primeri uspešnog povezivanja su razvoj odnosa i mreža odnosa između različitih učesnika u lancu vrednosti i identifikovanje posebnih uloga svakog učesnika u procesu upravljanja portfolijom. Rezultati različitih istraživanja koja su se odnosila na razmatranje ovih problema ukazuju na važnost dizajniranja i primene odgovarajućih organizacionih tehnika i pristupa za ostvarivanje ciljnih performansi inovacija. Upravljanje je uspešnije ako uključuje:

- korišćenje modela odlučivanja i monitoringa zasnovanih na dijagramu toka procesu razvoja projekata inovacija, 
- izbor i primenu efikasnih tehnika upravljanja projektima, koje stimulišu kreativnost,

- primenu odgovarajuće metodologije selekcije projekata inovacija koja je usaglašena sa poslovnim ciljevima i stepenom prihvatljivosti rizika.

- Poznato je da nema jedinstvenih pravila za upravljanje portfolijom inovacija koje uspešno mogu primeniti sva preduzeća. Međutim, istraživanja (npr. Jong i sar., 2013, str. 1-14) pokazuju da pouzdane rezultate obezbeđuje pristup koji obuhvata različite faze i odgovor na ključna pitanja:

- Prihvatanje procesa vođenja inovacija kao apsolutno kritičnog i definisanje različite hijerarhije ciljeva - Za uspešno upravljanje portfolijom inovacija potrebno je komunicirati viziju kako bi zaposleni u različitim područjima mogli da daju adekvatan doprinos. Veoma je značajno da se jasno definišu ciljevi na različitim hijerarhijskim nivoima i da se ostvari potrebna koordinacija menadžera različitih nivoa i funkcionalnih područja, od ideje do komercijalizacije inovacije;

- Ulaganje u koherentni i uravnoteženi portfolio inovacija koje imaju potencijal da omoguće ostvarivanje željenih prinosa uz prihvatanje vremenskog rizika - Kao što je već istaknuto, ne postoji univerzalno prihvatliiv miks projekata inovacija. Uspeh je izvesniji ukoliko se izbor projekata zasniva na odgovarajućim tehničko-tehnološkim i marketing istraživanjima, ako su ciljevi inovacija usaglašeni sa finansijskim i ostalim poslovnim ciljevima preduzeća, kao i sa poslovnom strategijom;

- Identifikovanje kritičnih resursa i sposobnosti za kreiranje vrednosti za ključne stejkholdere - U ekonomiji zasnovanoj na znanju upravljanje projektima inovacija je uspešnije ukoliko se zasniva na kreiranju i širenju znanja ne samo u kroz organizaciju, već i u eksternom okruženju. Zbog toga je potrebno da se sistematski pristupa ključnim problemima koje bi trebalo rešiti, da se sistematski istražuju i koriste postojeći i novi resursi znanja kako bi se kreirala odgovarajuća ponuda vrednosti;

- Kreiranje novih poslovnih modela kao osnove za razvoj distinktivnih i odbranjivih izvora profita - Doprinos pojedinih tipova inovacija poslovnim performansama preduzeća je različit. Svako konkretno preduzeće, u zavisnosti od ciljeva, izabranih strategija, resursa i sposobnosti kreira optimalni portfolio inovacija. Na primer, učešće transformacionih inovacija će biti veće $u$ predu- zećima koja imaju potencijal da kreiraju nova tržišta;

- Brz i efikasan razvoj i lansiranje projekata inovacija, kao osnove za sticanje i održavanje konkurentske prednosti - Sposobnost da se bude brži od konkurencije je ključna za uspešno upravljanje portfolijom inovacijama. Poznato je da je proces razvoja novog proizvoda/usluge veoma kompleksan, da uključuje različite nivoe, uloge i učesnike što može usporiti komercijalizaciju. Izbor adekvatnog načina tehnološkog i tržišnog testiranja inovacija može doprineti skraćivanju vremena za tržište, osvajanju tržišta i povećanju tržišnog učešća;

- Ocena da li se inovacije plasiraju na relevantnim tržištima, segmentima sa prihvatliivim profitnim potencijalom - Tip inovacije, ali i poslovna orijentacija preduzeća, uslovljavaju izbor segmenata tržišta i redosled njihovog osvajanja. Važno je da se uspešno uravnoteži taj proces u skladu sa postavljenim ciljevima;

- Povezivanje sa eksternim stejkholderima i zajednička realizacija projekata inovacija sa ciljem da se ostvare veći efekti - Prošlo je vreme kada je uspeh projekata inovacija prevashodno bio uslovljen sposobnostima istraživanja i razvoja i obimom ulaganja u ove aktivnosti. Danas se, sve više, insistira na kreiranju organizacione kulture i klime koje će podsticati kreiranje inovacionih i ostalih poslovnih mreža, uspešno upravljanje mrežom odnosa i korišćenje odnosa i mreža sa različitim stejkholderima kao izvora ideja za nove proizvode, usluge i procese;

- Mobilisanje zaposlenih, putem motivisanja, nagradivanja i vođenja, da kontinuirano unapređuju $i$ razvjaju nove projekte inovacija - Uspešna i održiva inovacija zahteva veliku energiju, uključenost i posvećenost svih zaposlenih. Posvećeni lideri i menadžeri su garant uspeha. Međutim, bez aktivnog uključivanja i doprinosa svih zaposlenih, rizik da se ne ostvare željeni ciljevi je veći. Neophodno je da se motiviše čitava organizacija, razvijanjem odgovarajuće kulture vrednosti. Jasno definisane uloge i odgovornosti su osnovna pretpostavka uspeha. Odgovarajuće individualno i organizaciono učenje su kritični faktor uspeha projekata inovacija. 


\section{ANALIZA PRAKSE UPRAVLJANJA PORTFOLIOM INOVACIJA U PREDUZEĆIMA U REPUBLICI SRBIJI}

Dizajn istraživanja - predmet, cilj i metodologija. Predmet empirijskog istraživanja u ovom radu jesu stavovi menadžera različitih funkcionalnih područja o potrebi strategijskog pristupa upravljanju portfolijom inovacija. Empirijsko istraživanje realizovano je korišćenjem metoda studije slučaja (de Vaus, 2001, str. 219-233). Korišćene su studije slučaja koje se zasnivaju na holističkim jedinicama analize i u okviru njih tzv. integrisane jedinice analize. Ovaj pristup je izabran jer su u donošenje strategijskih odluka uključeni menadžeri različitih nivoa i funkcionalnih područja. Preduzeće je holistički nivo slučaja, jedinica analize, ali „kompletna slika ove kompleksne jedinice istraživanja može se dobiti samo prikupljanjem podataka o svim učesnicima u odlučivanju, tzv. integrisanim jedinicama određene celine" (Yin, 1989).

U slučajevima kada se koristi holistička jedinica analize poželjno je koristiti različite načine za prikupljanje podataka. Za potrebe boljeg razumevanja predmeta našeg istraživanja korišćena je kvalitativna analiza koja je pogodna zbog činjenice da je reč o preliminarnim istraživanjima. Cilj je sagledavanje i razumevanje načina na koji menadžeri u Srbiji upravljaju portfolijom inovacija i sticanje uvida u to da li koriste pristupe koji su poznati u teoriji i praksi uspešnih preduzeća.

Za prikupljanje podataka korišćen je dubinski intervju kao tehnika ispitivanja. Podsednik za vođenje intervjua, kao istraživački instrument, pored ostalih, se odnosio i na sledeće teme:

- Mišljenja i stavovi menadžera o značaju inovacija za uspešno strategijsko pozicioniranje preduzeća i njihovo znanje o pristupima upravljanja koji se koriste u praksi, kao i stavovi o potrebi usklađivanja inovacione i poslovne strategije preduzeća;

- Tipovi inovacija koje menadžeri mogu identifikovati u svojim preduzećima; da li se meri doprinos inovacija poslovnom uspehu preduzeća;

- Praksa upotrebe izabranih merila za utvrđivanje doprinosa pojedinih tipova inovacija i nivo kompleksnosti pojedinih merila.

Prva tema omogućila je prikupljanje informacija koje su služile kao osnova u istraživanju i odnose se na mišljenje menadžera i praksu preduzeća u Srbiji vezanu za pristupe upravljanju inovacijama. Druge dve omogućavaju da se analiziraju konkretna praksa, tipovi inovacija, njihov značaj, načini i merila koj se koriste u izabranim preduzećima.

Podaci su prikupljeni korišćenjem fokus grupa. Istraživanje je realizovano u preduzećima sa privatnim kapitalom koja posluju u različitim oblastima. Izabrano je deset proizvodnih preduzeća koja posluju najmanje 10 godina, koja su u periodu 2011-2014.godine ostvarila dobitak i koja su u posmatranom periodu realizovala inovacije (tabela 1). Istraživanjem je obuhvaćeno 50 menadžera različitih profila (top menadžeri, menadžeri proizvodnje, istraživanja i razvoja, finansija i marketinga).

TABELA BROJ 1: Karakteristike ispitivanih preduzeća

\begin{tabular}{|c|c|c|c|c|c|c|}
\hline $\begin{array}{l}\text { Red. } \\
\text { Br. }\end{array}$ & Veličina & $\begin{array}{c}\text { Šifra } \\
\text { delatnosti }\end{array}$ & $\begin{array}{l}\text { Promene } \\
\text { prihoda u } \\
\text { periodu } 2011 \text { - } \\
\text { 2014. godine }\end{array}$ & $\begin{array}{l}\text { Stopa prinosa } \\
\text { (ROA) u } \\
\text { periodu 2011- } \\
\text { 2014. godine }\end{array}$ & $\begin{array}{l}\text { Ulaganja u I \&R } \\
\text { u periodu } 2011 \text { - } \\
2014 \text { godine } \\
\text { \% u odnosu na } \\
\text { ukupn prihod }\end{array}$ & $\begin{array}{l}\text { Konkurentska } \\
\text { pozicija u } \\
\text { periodu } 2011 \text { - } \\
\text { 2014. godine }\end{array}$ \\
\hline 1. & Veliko & 1032 & Smanjenje & Rast & Isti \% & Jaka \\
\hline 2. & Veliko & 1072 & Rast & Povećanje & Povećanje & Jaka \\
\hline \multicolumn{7}{|l|}{3.} \\
\hline 4. & Srednje & 1089 & Rast & Rast & Isti \%e & Povoljna \\
\hline 5. & Veliko & 1102 & Smanjenje & Smanjenje & Povećanje & Povoljna \\
\hline 6. & Srednje & 1107 & Rast & Stagnacija & Isti \% & Jaka \\
\hline 7. & Srednje & 2012 & Rast & Stagnacija & Isti \% & Povoljna \\
\hline 8. & Srednje & 2020 & Rast & Stagnacija & Isti \% & Povoljna \\
\hline 9. & Srednje & 2059 & Rast & Povećanje & Isti \% & Povoljna \\
\hline 10. & Veliko & 2211 & Rast & Povećanje & Povećanje & Jaka \\
\hline 11. & Veliko & 2752 & Smanjenje & Smanjenje & Isti \% & Povoljna \\
\hline
\end{tabular}


TABELA BROJ 2: Stavovi menadžera o značaju strategijskog pristupa upravljanja inovacijama

\begin{tabular}{|c|c|c|c|c|c|c|c|}
\hline $\begin{array}{l}\text { R. br. } \\
\text { predu- } \\
\text { zeća }\end{array}$ & Tip inovacija & $\begin{array}{l}\text { Struktura } \\
\text { inovacija }\end{array}$ & $\begin{array}{c}\text { Značaj } \\
\text { inovacija }\end{array}$ & $\begin{array}{l}\text { Vrednovanje } \\
\text { doprinosa } \\
\text { inovacija }\end{array}$ & \begin{tabular}{|c|} 
Merila za \\
vrednovanje \\
inovacija
\end{tabular} & $\begin{array}{l}\text { Uskladenost } \\
\text { strategije } \\
\text { inovacija sa } \\
\text { poslovnom } \\
\text { strategijom }\end{array}$ & $\begin{array}{l}\text { Interfunkcio- } \\
\text { nalna sarad- } \\
\text { nja u procesu } \\
\text { upravljanja } \\
\text { portfolfjom }\end{array}$ \\
\hline 1. & $\begin{array}{l}\text { Inovacije proi- } \\
\text { zvoda, procesa, } \\
\text { u organizaciji i } \\
\text { marketingu }\end{array}$ & $\begin{array}{l}\text { Suštinske } \\
\text { Srodne }\end{array}$ & $\begin{array}{l}\text { Veoma } \\
\text { značajne }\end{array}$ & $\begin{array}{l}\text { Neadekvatno } \\
\text { vrednovanje } \\
\text { inovacija }\end{array}$ & $\begin{array}{l}\text { Finansijska } \\
\text { Nefinansijska }\end{array}$ & $\begin{array}{l}\text { Nedovoljna } \\
\text { usklađenost* }\end{array}$ & $\begin{array}{l}\text { Neophodna su } \\
\text { unapređenja }\end{array}$ \\
\hline 2. & $\begin{array}{l}\text { Inovacije proi- } \\
\text { zvoda, procesa, } \\
\text { u organizaciji i } \\
\text { marketingu }\end{array}$ & $\begin{array}{l}\text { Suštinske } \\
\text { Srodne }\end{array}$ & $\begin{array}{l}\text { Veoma } \\
\text { značajne }\end{array}$ & $\begin{array}{l}\text { Neadekvatno } \\
\text { vrednovanje } \\
\text { inovacija }\end{array}$ & $\begin{array}{l}\text { Finansijska } \\
\text { Nefinansijska }\end{array}$ & $\begin{array}{l}\text { Nedovoljna } \\
\text { usklađenost }\end{array}$ & $\begin{array}{l}\text { Neophodna su } \\
\text { unapređenja }\end{array}$ \\
\hline 3. & $\begin{array}{l}\text { Inovacije u } \\
\text { organizaciji i } \\
\text { marketingu }\end{array}$ & Suštinske & Značajne & $\begin{array}{l}\text { Neadekvatno } \\
\text { vrednovanje } \\
\text { inovacija }\end{array}$ & $\begin{array}{l}\text { Finansijska } \\
\text { Nefinansijska }\end{array}$ & Neusklađena & $\begin{array}{l}\text { Neophodna su } \\
\text { unapređenja }\end{array}$ \\
\hline 4. & $\begin{array}{l}\text { Inovacije } \\
\text { proizvoda, u } \\
\text { organizaciji i } \\
\text { marketingu }\end{array}$ & Suštinske & Značajne & $\begin{array}{l}\text { Neadekvatno } \\
\text { vrednovanje } \\
\text { inovacija }\end{array}$ & $\begin{array}{l}\text { Finansijska } \\
\text { Nefinansijska }\end{array}$ & $\begin{array}{l}\text { Nedovoljna } \\
\text { usklađenost }\end{array}$ & $\begin{array}{l}\text { Neophodna su } \\
\text { unapređenja }\end{array}$ \\
\hline 5. & $\begin{array}{l}\text { Inovacije proce- } \\
\text { sa, u organizaci- } \\
\text { ji i marketingu }\end{array}$ & Suštinske & Značajne & $\begin{array}{l}\text { Neadekvatno } \\
\text { vrednovanje } \\
\text { inovacija }\end{array}$ & $\begin{array}{l}\text { Finansijska } \\
\text { Nefinansijska }\end{array}$ & Neusklađena & $\begin{array}{l}\text { Neophodna su } \\
\text { unapređenja }\end{array}$ \\
\hline 6. & $\begin{array}{l}\text { Inovacije proi- } \\
\text { zvoda, procesa, } \\
\text { u organizaciji i } \\
\text { marketingu }\end{array}$ & Suštinske & Značajne & $\begin{array}{l}\text { Neadekvatno } \\
\text { vrednovanje } \\
\text { inovacija }\end{array}$ & $\begin{array}{l}\text { Finansijska } \\
\text { Nefinansijska }\end{array}$ & Neusklađena & $\begin{array}{l}\text { Neophodna su } \\
\text { unapređenja }\end{array}$ \\
\hline 7. & $\begin{array}{l}\text { Inovacije } \\
\text { proizvoda i u } \\
\text { marketingu }\end{array}$ & Suštinske & Značajne & $\begin{array}{l}\text { Neadekvatno } \\
\text { vrednovanje } \\
\text { inovacija }\end{array}$ & $\begin{array}{l}\text { Finansijska } \\
\text { Nefinansijska }\end{array}$ & Neusklađena & $\begin{array}{l}\text { Neophodna su } \\
\text { unapređenja }\end{array}$ \\
\hline 8. & $\begin{array}{l}\text { Inovacije } \\
\text { proizvoda, i u } \\
\text { Organizaciji }\end{array}$ & Suštinske & Značajne & $\begin{array}{l}\text { Neadekvatno } \\
\text { vrednovanje } \\
\text { inovacija }\end{array}$ & $\begin{array}{l}\text { Finansijska } \\
\text { Nefinansijska }\end{array}$ & Neusklađena & $\begin{array}{l}\text { Neophodna su } \\
\text { unapređenja }\end{array}$ \\
\hline 9. & $\begin{array}{l}\text { Inovacije proi- } \\
\text { zvoda, procesa, } \\
\text { u organizaciji i } \\
\text { marketingu }\end{array}$ & $\begin{array}{l}\text { Suštinske } \\
\text { Srodne }\end{array}$ & $\begin{array}{l}\text { Veoma } \\
\text { značajne }\end{array}$ & $\begin{array}{l}\text { Neadekvatno } \\
\text { vrednovanje } \\
\text { inovacija }\end{array}$ & $\begin{array}{l}\text { Finansijska } \\
\text { Nefinansijska }\end{array}$ & Neusklađena & $\begin{array}{l}\text { Neophodna su } \\
\text { unapređenja }\end{array}$ \\
\hline 10. & $\begin{array}{l}\text { Inovacije proi- } \\
\text { zvoda, procesa, } \\
\text { u organizaciji i } \\
\text { marketingu }\end{array}$ & Suštinske & $\begin{array}{l}\text { Veoma } \\
\text { značajne }\end{array}$ & $\begin{array}{l}\text { Neadekvatno } \\
\text { vrednovanje } \\
\text { inovacija }\end{array}$ & $\begin{array}{l}\text { Finansijska } \\
\text { Nefinansijska }\end{array}$ & Neusklađena & $\begin{array}{l}\text { Neophodna su } \\
\text { unapređenja }\end{array}$ \\
\hline
\end{tabular}

* Menadžeri su ocenjivali usklađenost strategije inovacija sa poslovnom strategijom kao: potpu nu usklađenost, nedovoljnu usklađenost i neusklađenost.

Analiza rezultata istraživanja. Analiza mišljenja i stavova menadžera izabranih preduzeća pokazuje da postoji opšta saglasnost o značaju inovacija za rast i razvoj preduzeća. Svi učesnici fokus grupa inovaciju ubrajaju u strategijske prioritete (tabela broj 2) što je u skladu sa preovlađujućim stavovima u relevatnoj teoriji i praksi. Menadžeri shvataju značaj inovacija što se može zaključiti iz njihovih stavova o potrebi kontinuiranog ulaganja u razvoj novih proizvoda, usluga i procesa. Međutim, iako se shvata značaj inovacija, identifikovane su razlike o značaju pojedinih funkcionalnih strategija i potrebi njhovog usklađivanja sa vizijom, ciljevima i poslovnom strategijom. 
Polazeći od teorijskih osnova izloženih u prethodnom tekstu, namera je bila da se istraži koji tipovi inovacija ( polazeći od kriterijuma koliko su nove za preduzeće i tržište) se realizuju u preduzećima koja su obuhvaćena istraživanjem. Cilj ovog dela istraživanja bio je da menadžeri identifikuju tip inovacija koje realizuju:

\section{- Inovacije na postojećim proizvodima za postojeća} tržišta (suštinske) - sa kontinuiranim unapređenjima, pre svega procesa, organizacije i marketinga, koje optimalno kombinuju postojeće proizvode i aktivu zadovoljavanjem potreba postojećih potrošača,

- Srodne - koje pretpostavljaju ulazak u nove poslove, nove za preduzeće, kao i ulazak na nova tržišta;

- Transformacione - inovacije kojima se kreiraju novi proizvodi i aktiva i nova tržišta.

Istraživanja pokazuju da su zastupljena dva tipa inovacija: suštinske i srodne. Iako ostvaruju povoljne finansijske rezultate $i$, po mišljenju menadžera, zadovoljavajuću konkurentsku poziciju, u portfoliu njihovih inovacija nisu zastupljene transformacione inovacije odnosno proizvodi preokreta. Dominiraju suštinske inovacije odnosno izvedeni projekti inovacija. Srodne inovacije realizovala su samo tri preduzeća (tabela broj 2).

Iako inovaciju posmatraju kao prioritet, menadžeri su svesni da im nedostaju resursi, ali i sposobnosti, da razvijaju nove proizvode kojima se kreiraju i nove potrebe potrošača, odnosno razvijaju nova tržišta. Shvataju potrebu povezivanja sa različitim stejkholderima, kako bi povećali učešće srodnih inovacija u portfoliju kao osnove za povećanje stope prinosa na ulaganja.

Ključni problem čije rešavanje može uticati na uspeh u upravljanju portfolijom inovacija je odsustvo pouzdanog vrednovanja njihovog doprinosa poslovnom uspehu preduzeća. Zaključak je da je većina menadžera nezadovoljna načinima vrednovanja inovacija i merilima koja se koriste u njihovoj poslovnoj praksi. Preduzeća koriste nekoliko merila, pre svega finansijskih (stopa rasta prihoda, procenat prihoda od novih proizvoda/usluga i procenat prihoda od novih kupaca) za vrednovanje inovacija, ali su svesni problema povezivanja ulaganja u inovacione aktivnosti i vrednovanja njihovog doprinosa poslovnim performansama preduzeća. Ohrabruje informacija da im je poznato da uspešne kompanije koriste strategijski sistem merenja sa više indikatora i mišljenje većina učesnika istraživanja da je neophodno da se započne sa razvijanjem odgovarajućih sistema vrednovanja ulaganja u inovacione aktivnosti. Holistički pristup vrednovanju inovacija, koji predstavlja osnovu za uspešno strategijsko upravljanje portfolijom je osnova za efikasno strategijsko odlučivanje i upravljanje.

\section{ZAKLJUČNA RAZMATRANJA}

U ekonomiji zasnovanoj na znanju, inovacije su ključni faktor uspeha preduzeća. Teorija i praksa pokazuju da su uspešnije privrede i preduzeća čiji se rast zasniva na inovacijama. Takođe je opšte poznato da postoje različiti tipovi inovacija i da se koriste različiti kriterijumi za njihovo razvrstavanje. Za efikasno strategijsko upravljanje portfolijom inovacija značajno je razvrstavanje polazeći od toga da li je reč o inovacijama na postojećim proizvodima i uslugama koji se prodaju na postojećim tržištima, o novim proizvodima/uslugama koji se prodaju na postojećim tržištima, ili novim poslovima za koje je neophodno kreirati i nova tržišta.

Realizovano eksploratorno istraživanje u izabranim preduzećima u Srbiji pokazuje da su u njihovom portfoliju inovacija prevashodno zastupljene tzv. suštinske inovacije. Iako menadžeri inovacije ubrajaju u top prioritete, neadekvatno vrednovanje njihovog doprinosa otežava optimizaciju portfolija inovacija. U praksi menadžmenta portfolijom inovacija nedostaju pojedini elementi strategijskog pristupa (nedovolja primena otvorenih modela inovacija, odgovarajuća interfunkcionalna i interorganizaciona koordinacija i dr.).

Ovo istraživanje je samo početi korak $\mathrm{u}$ ispitivanju stanja prakse u preduzećima u Republici Srbiji i može poslužiti kao osnova za detaljnija istraživanja. 


\section{Literatura}

1. Anderson, D.K. \& Mern, A. (2003). „Project management strategy - project management represented as a process based set of management domains and the coequences for project management strategy". International Journal of Project Management, Vol. 21, pp. 387-393.

2. Artto, K.A., Dietrich P.H. (2004), Strategic Business Management through Multiple Projects, U: The Wiley Guide to Managing Projects, John Wiley and Sons, Inc.

3. Blichfeldt, B.S. \& Eskerod, P. (2008). „Project portfolio management - Theres more to it than what management enacts“. International Journal of Project Management, Vol. 26, pp. 257-365.

4. Bard, J.F:, Balachandra, R., Kaufman, P.E. (1988). „An interactive approach to R\&D project selection ad terination", IEEE Transactions on Engineering Management, Vol. 35, pp. 139-46.

5. Christensen, C.M., Raynor, M.E., (2003), The Inovators Solution: Creating and Sustaining Successful Growth, Harvard Business School Publishing Corporation, Boston.

6. Cooper, R.G., Edgett, S.J. (2014) New Problems, New Solutions: Making Portfolio Management More Effective, Product Development Institute, Inc. Dostupno na: http://www.stage-gate.net/downloads/ wp/wp_09.pdf (pristupljeno 24.10.2015)

7. Doyle, P.\& Stern, Ph. (2006), Marketing Management and Strategy (fourth edition), Prentice Hall.

8. Davenport, T., Leibold, L., Voelpel, S. (2006), Strategic Management in the Innovation Economy - Srategic Approaach and Tools for Dynamic Innovation Capabilities, Publicis and Wiley.

9. Englund, R.L. \& Graham, R. J. (1999). „From Experience: Linking Projects to Strategy“. Journal of Production and Inovation Management, Vol. 16, No. 1, pp. 52-64.

10. Henderson, R. M. \& Clark, K.. B. (1990), „Architectural Innovation: The Reconfiguration Of Existing “, Administrative Science Quarterly, March, pp. 9-30.

11. Jackson S.E., Joshi, A. \& Erhardt, N.L. (2003). „Recent research o team and orgainzational diversity: SWOT analysis and implications". Journal of Organizational Behaviour, Vol. 25, pp. 801-830.

12. Jamieson A. and Morris . W. G. (2007). „Moving from Corporate Strategy to Project Strategy“, u: The Wiley Guide to Project, Program and Portfolio Management (authors: Peter Morris, Jeffrey K. Pinto), John Wiley and Sons, New Jersey.
13. Jong, M., Marston, N., Erik, Roth, E., Biljon P. (2013), The Eight Essentials of Innovation Performance, http:// www.mckinsey.com/business-functions/strategy-andcorporate-finance/our-insights/the-eight-essentialsof-innovation.pdf, (pristupljeno 25.10.2015)

14. Levine, R. (2005) Finance and Growth: Theory and Evidence. Handbook of Economic Growth 1, str. 865934.

15. Milisavljević, M., (2006), Marketing, Savremena administracija, Beograd.

16. Milisavljević, M. (2012), Strategijski menadžment: analiza, izbor, promena, Centar za izdavačku delatnost, Ekonomski fakultet Beograd.

17. Mobornj, R., Kim, Č.V. (2007), Strategija plavog okeana (prevod), Krug press, Beograd.

18. Mohr, J.S., Slater, S. (2006), Marketing of HighTechnology Products and Innovations, second edition, Pearson Education, Inc. New Jersey.

19. Nagsi, B., Tuff, G. (2012), „Managing Your Innovation Portfolio", Harvard Business Review, May.

20. OECD (2005), Oslo Manual: Guidelines for Collecting and Interpreting Innovation Data, 3rd Edition, http:// www.oecd.org/sti/inno/oslomanualguidelinesforcollectingandinterpretinginnovationdata3rdedition. htm, (pristupljeno 24.10.2015).

21. PMI: (2006), The Standard for Portfolio Managament, Project Management Institute, Newton Square, PA.

22. Rajegopal S., McGuin, P., Walter, J. (2007). Poject portfolio management: leading the corporate vision. Palgrave, London.

23. Senić, R. (2003), Marketing Menadžment, Prizma, Kragujevac.

24. Simenis, E., Hart, S. (2009), „Inovation from the Inside out", MIT Sloan Management Review, Vol. 50 (4), str. 77-87.

25. Srivannboon, S., Miloševic, D. A. (2006). „A Twoway Influence Between Business Strategy and Project Management", International Journal of Project Management, Vol. 24, No. 6, pp. 493-505.

26. Republički zavod za statistiku (2011). Statistički godišnjak Republike Srbije, Republički zavod za statistiku, Beograd.

27. Wheelwright, S.C. \& Clark, K.B. (2011). Revolutionizing Product Developmen: Quantum Leeps in Speed, Efficiency and Quality. The Free Press, New York.

28. Yin, R.K. (1989). „Case study research: Design and methods“. Applied Social Research Series, Vol, 5. Sage, London. 
Abstract:

\title{
Strategic Innovation Portfolio Management
}

\author{
Ljiljana Stanković, Suzana Đukić
}

In knowledge-based economy, strategic innovation portfolio management becomes more and more important and critical factor of enterprise's success. Value creation for all the participants in value chain is more successful if it is based on efficient resource allocation and improvement of innovation performances. Numerous researches have shown that companies with best position on the market found their competitiveness on efficient development and exploitation of innovations. In decision making process, enterprise's management is constantly faced with challenge to allocate resources and capabilities as efficiently as pos-

sible, in both short and long term. In this paper authors present preliminary results of realized empirical research related to strategic innovation portfolio management in ten chosen enterprises in Serbia. The structure of the paper includes the following parts: theoretical background, explanation of research purpose and methodology, discussion of the results and concluding remarks, including limitations and directions for further research.

Keywords: strategic management, innovation portfolio, innovation evaluation, innovation performances

Rad je rezultat rada na Projektu 47005 koje finansira

Ministarstvo prosvete, nauke i tehnološkog razvoja Republike Srbije.

KONTAKT:

dr Ljiljana Stanković, redovni profesor ljiljana.stankovic@eknfak.ni.ac.rs

dr Suzana Đukić, vanredni profesor suzana.djukić@eknfak.ni.ac.rs

Ekonomski fakultet Univerziteta u Nišu Trg Kralja Aleksandra Ujedinitelja 11

18000 Niš 